May 2013

\title{
Library Cartoons: A Literature Review of Library-themed Cartoons, Caricatures, and Comics
}

Julia B. Chambers

SJSU SLIS, jhbchambers@gmail.com

Follow this and additional works at: https://scholarworks.sjsu.edu/ischoolsrj

Part of the Library and Information Science Commons

\section{Recommended Citation}

Chambers, J. B. (2013). Library Cartoons: A Literature Review of Library-themed Cartoons, Caricatures, and Comics. School of Information Student Research Journal, 3(1). https://doi.org/10.31979/ 2575-2499.030102 Retrieved from https://scholarworks.sjsu.edu/ischoolsrj/vol3/iss1/2

This article is brought to you by the open access Journals at SJSU ScholarWorks. It has been accepted for inclusion in School of Information Student Research Journal by an authorized administrator of SJSU ScholarWorks. For more information, please contact scholarworks@sjsu.edu. 


\title{
Library Cartoons: A Literature Review of Library-themed Cartoons, Caricatures, and Comics
}

\begin{abstract}
To understand differing views of past events, historians, political science scholars, and sociologists have analyzed political and editorial cartoons with themes ranging from elections to fiscal policy to human rights. Yet scant research has been dedicated to cartoons with library themes. The author of this paper examines peer-reviewed literature on the subject of library cartoons, including historical background, analysis of recent themes, and arguments for promoting library-themed cartoons, caricatures, and comics. The author finds a significant gap in the literature on this topic and concludes that information professionals would benefit from a comprehensive content analysis of library-themed cartoons to enhance understanding of the significance of libraries during historic events, assess public perception of libraries, and identify trends over time.
\end{abstract}

\section{Keywords}

library cartoons, librarian cartoons, library-themed cartoons, library caricature, editorial cartoon analysis, political cartoon analysis, library humor, cartoons about libraries, cartoons about librarians

\section{About Author}

Julia B. Chambers is a MLIS candidate at San Jose State University's School of Library \& Information Science. She holds a BA in Political, Legal, and Economic Analysis from Mills College, in Oakland, California. 
LIBRARY CARTOONS:

\section{A Literature Review of LibraRy-Themed CARTOONs, CARICATURES, AND} COMICS

Scholars have discussed and analyzed the influence and value of editorial cartoons in the United States since the start of the $20^{\text {th }}$ century, not long after cartoons became a regular feature in East Coast newspapers. In a 1933 article, American art and literary critic Elizabeth Luther Cary argued that American caricature provided insight into history, revealing attitudes or alternative attitudes that newspapers and history books have otherwise failed to record. Twenty years later, Stephen Becker (1959), author of Comic Art in America, concurred that early examples of caricature served to fill journalistic voids, sometimes acting as the only acceptable outlet for commentary too vulgar or sensitive to appear in written editorials. Richard Felton Outcault's Yellow Kid editorial cartoons, published in 1896 in the New York World, are one example: "[Yellow Kid] brought something new and upsetting into American homes: the slums, and slum kids, and ordinary cruelty, and slang, and the cockiness of poverty" (Becker, 1959, p. 13).

Contemporary editorial cartoons continue to serve as an acceptable format for airing controversial views (Kuipers, 2011), often with the intent of swaying public opinion. In a study of political cartoons with presidential election themes, Edwards and Ware (2005) examined the impact of editorial cartoons on public opinion and concluded that negative caricatures of voters contributed to public apathy toward the electoral process. Similar conclusions about the power of comic art to influence public opinion were reported in a study by Josh Greenberg (2002), whose research suggested that cartoons may help people interpret life events. In contrast, other scholars have examined political cartoons as a reflection of public opinion rather than an instigator of thought. However the literature, here, presents contradictory conclusions. Edward Holley and Norman Stevens (1969), for instance, argue that cartoons are an accurate portrayal of public opinion, while others point to evidence indicating that cartoons do not necessarily reflect the general view nor serve as timely portraits of historic events (Gilmartin \& Brunn, 1998; Meyer, Seidler, Curry, \& Aveni, 1980).

Studied as art forms (Robb, 2009), Zeitgeist ephemera (Holley \& Stevens, 1969), primary sources (Thomas, 2004), and even agents of change (Edwards \& Ware, 2005; see also Marin-Arrese, 2008; Neuberger \& Kremar, 2008), editorial cartoons have been the subject of analysis in a variety of academic disciplines. However, scant research has been dedicated to the subject of cartoons or caricatures containing library themes. In fact, the author of this literature review found only one study, conducted by Alireza Isfandyari-Moghaddam and Vahideh Kashi-Nahanji (2010), devoted to the content analysis of themes in a small 
selection of library cartoons, and that study failed to describe its selection process or the method of content analysis used.

Yet library-themed cartoons exist in abundance and date back to the late 1800s. Library cartoons not only offer a wide range of commentary on librarians, library funding, and the digitization of information, but they also provide unique insight into the history of libraries in the U.S. For example, a prominent textbook used in introductory library science classes, Foundations of Library and Information Science by Richard E. Rubin (2010), presents a laudatory view of Andrew Carnegie's \$56 million contribution toward the construction of thousands of libraries across America (p. 60). While Rubin does note that some people criticized Carnegie's donations as a form of social control, there is no mention of the public's outrage over the tax burden they created. Nor is there mention of the view held by some that the construction of these libraries was merely about Carnegie's ego rather than about the public good. Yet a number of editorial cartoons, such as the two examples below, satirize Carnegie's philanthropy, deride his ego, and issue commentary on the tax burden ultimately produced by his gift of public libraries to cities around the country.

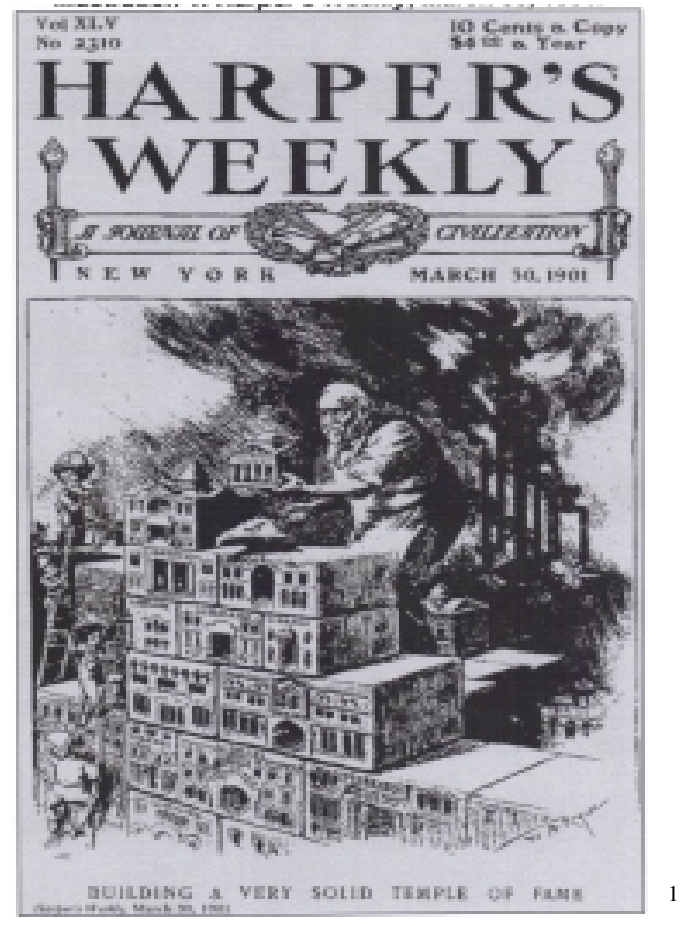

\footnotetext{
${ }^{1}$ Author unknown. 1901, Harper's Weekly. This work is in the public domain in the United States because it was published (or registered with the U.S. Copyright Office) before January 1, 1923.
} 


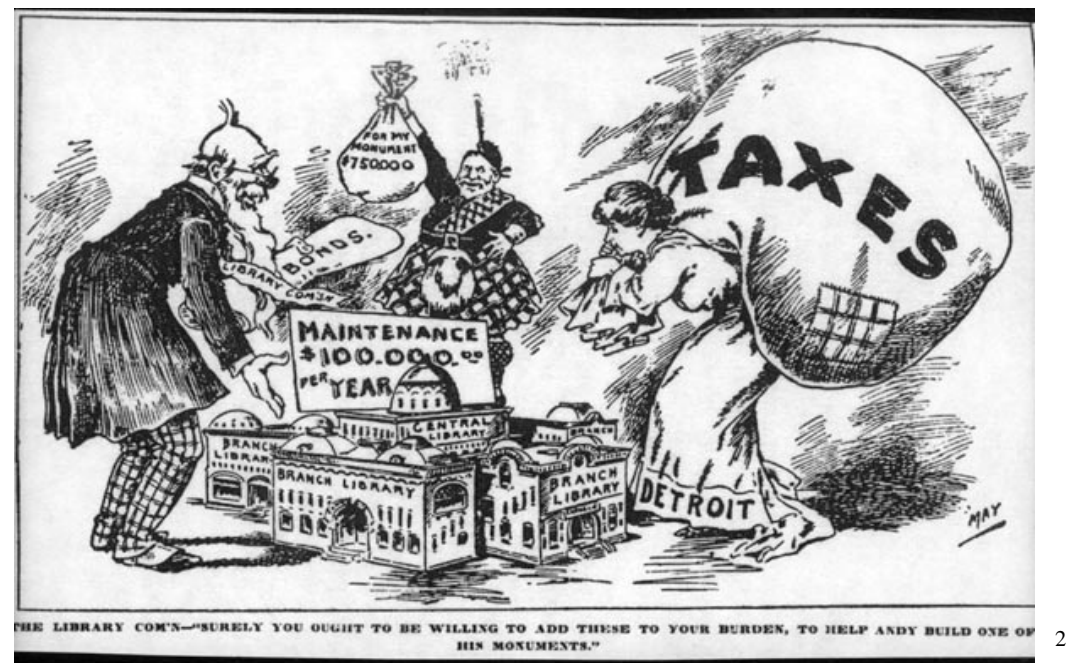

Despite the rich history of library cartoons, many research questions about cartoons containing library themes have never been addressed in the literature. For instance, what were some of the earliest library cartoons in this country? What were common themes? Have the themes changed over the years especially since the Internet became a widespread research tool? Most importantly, does the study of library cartoons matter?

This review of scholarly literature on the topic of library cartoons identifies previous areas of study, highlights some thematic trends, and argues that a comprehensive content analysis of library-themed cartoons would contribute to the field of library science in the same way that scholars in other disciplines have used editorial cartoons to supplement their understanding of historic events, explore public perception, and identify trends. This paper provides an overview of what has been written on the topic, including some library cartoon history, noted themes, and scholarly interpretation of those themes. Looking at research on the broader topic of editorial cartoon analysis identifies some of the areas of research that have yet to be conducted in the study of library-themed cartoons.

\section{LITERATURE REVIEW}

The existing literature on library-themed cartoons, caricatures, and comics explores three dominant areas: historical trends, modern themes, and the value of library-themed cartoons to the field of library science. The literature comes in the form of one research study, essays written by information professionals, and

\footnotetext{
${ }^{2}$ May, 1902, The Detroit Journal. This work is in the public domain in the United States because it was published (or registered with the U.S. Copyright Office) before January 1, 1923.
} 
articles written by scholars who promote the importance of studying comic art. This paper reviews the literature dedicated to each of these areas.

\section{Historical Trends}

Critical to any academic study is an historical overview of the topic. Unfortunately, the existing literature on library comic art covers very little history of the subject. Editorial and political cartoons, however, have held a prominent place in American journalism dating as far back as 1754 when Benjamin Franklin illustrated his famous "Join, or Die" editorial cartoon. His image of a severed snake, published in The Pennsylvania Gazette on May 9, 1754, was Franklin's attempt to illustrate the necessity of colonial unity (Dewey, 2007, p. 2; Thomas, 2004, p. 426).

By the late 1880s, political cartoons began to appear regularly in U.S. newspapers (Becker, 1959, p. 7; Hess \& Northrop, 1996, pp. 68-70). From the beginning, newspaper cartoons had a satirical bent, though one scholar noted a decided shift in the early $20^{\text {th }}$ century from political to social themes (Cary, 1933). Newspapers' political cartoons were influential, particularly, because a good portion of the population was illiterate. Some of these early cartoons have been credited with influencing politics and even elections (Dewey, 2007, pp.34-35).

Turn-of-the-century library cartoons. Cartoons with library themes were not particularly common around the turn of the $20^{\text {th }}$ century, but a search for "library cartoons" through a variety of online databases and print collections produced many historical examples with a predominantly satirical bent. One editorial cartoon dating 1892 mocks the inaccessible hours of the Astor Library in New York City.

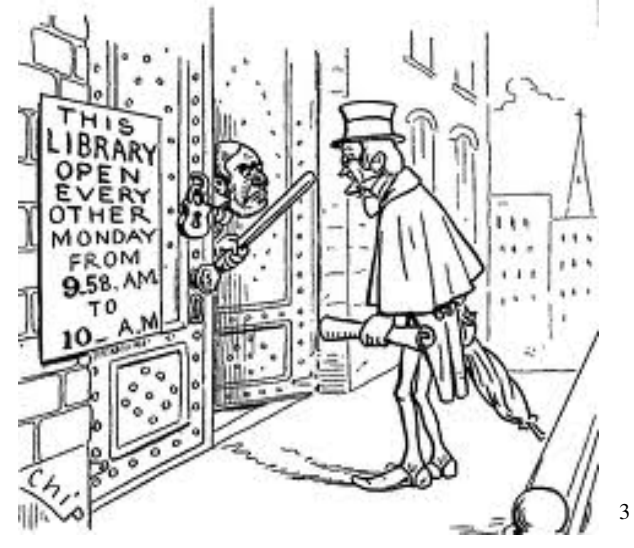

${ }^{3}$ Chip, 1892, Life magazine. This work is in the public domain in the United States because it was published (or registered with the U.S. Copyright Office) before January 1, 1923. 
Between the early 1900s and World War II, satire continued to be popular in editorial and political cartoons, but new themes emerged in the genre. In the 1920s, the family-themed comic strips of today began to appear in newspapers around the country. Consequently, a lighter humor and what could be called a more earnest commentary entered the comic art form. Researcher Ilan Danjoux (2007), at the University of Manchester, attributes this shift to the development of syndication: "Cartoonists seeking to profit from syndication sanitized their commentary for wide audience appeal" (p. 247). Libraries were not a common theme, but one example of newly sanitized caricature is evident in a 1938 cartoon, published in the New Yorker, in which the stone lion statues Patience and Fortitude, who guard the entrance of the New York City Public Library, are reading books. The caption, "a revised statuary for the city of tomorrow," depicts a metropolis filled with educated readers (Taylor, 1938).

Midcentury Super-librarian. Midcentury library cartoons gave birth to a radical new image in the field of library science: The Librarian Superhero. In his article "Look! Up in the Sky! It's a Librarian!," Robert Hulshof-Schmidt (2008) identifies several superhero librarians featured in comic books, beginning with perhaps the most famous: Gotham City librarian Barbara Gordon, aka Batgirl, who made her Detective Comics debut in 1967. Hulshof-Schmidt notes that Batgirl remained a DC Comics hero for decades, but reinvented herself as "Oracle" in the late 1980s following an accident that left her wheelchair-bound. She maintained her librarian persona by operating a computerized information network for her Bird of Prey comrades, depicting, in essence, the first digital librarian.

Two notable librarian superheroes emerged in comics of the 1980s. Xi' an Coy Mahn, of Marvel Comics, was a second generation X-man leader of the "New Mutants," who served as a librarian at the University of Chicago and the Xavier Institute. Blok, a member of the Legion of Super-Heros, was a rock-like comic character who acted as a quasi-reference librarian to his superhero colleagues (Hulshof-Schmidt, 2008).

Millennium cartoons. Cartoons of the 1990 s and early $21^{\text {st }}$ century reveal a blossoming of library themes. The librarian-in-disguise motif continued to evolve: In 1990, Preservation Graphics introduced a short-lived comic, "The Incredible Librarian," which featured superhero Maria Norlander-Martinez, an undercover preservationist librarian who prevented villains from destroying books (Hulshof-Schmidt, 2008). In 2004, DC Comics reintroduced a super-villain character from the late 1960s, The Calculator, who managed a computerized information network for the bad guys (2008).

In addition to comics featuring Super-librarians, library-themed cartoons continue to flourish with political, editorial, satirical, and comical undertones. In fact, most cartoon database searches conducted in the research of this paper 
yielded library-themed cartoons published predominantly after 1995. Over the past two decades, cartoons with library themes have even begun to appear frequently in popular syndicated comic strips including Baby Blues, Bizarro, Bloom County, Family Circus, Far Side, Frank and Ernest, For Better or For Worse, and Ziggy (Bergson, 2002). Comic strips based entirely in library settings have also recently emerged, including Unshelved (Plourde, 2011) and Liberry Funnies (Wagner, 2005). The literature does not suggest whether the number of cartoons with library themes has increased or cartoon databases simply contain more library cartoons from this time period than from previous eras. However, a review of Charles Brooks's annual serial publication, Best Editorial Cartoons of the Year (1990-2010), shows the majority of library-themed cartoons in print occurring in the late 1990s and beyond.

\section{THEMATIC HighLIGHTS}

A review of the literature on library-themed cartoons revealed only one research study dedicated to identifying themes in library cartoons. In that 2010 study, authors Alireza Isfandyari-Moghaddam and Vahideh Kashi-Nahanji, from the Department of Library and Information Studies at Islamic Azad University, Hamedan Beach, Iran, used a content analysis research method to analyze and categorize 255 caricatures containing library science themes. The purpose of their study was to use library-themed caricatures to identify negative themes and weaknesses in the field of Library and Information Science that had previously escaped debate from information professionals.

The study by Isfandyari-Moghaddam and Kashi-Nahanji (2010) has several shortcomings. The authors fail to explain the criteria used for their cartoon selection, so it is unclear how they sampled the library-themed cartoons in their analysis. Their selection is limited to cartoons published within the past two decades. The authors include library cartoons created by one of the principal researchers with no indication that measures were taken to avoid bias in their analysis. Furthermore, the study lacks description of the content analysis method employed. Nevertheless, this is the only study that categorizes themes in library cartoons, and therefore it establishes a starting point for future studies.

The following four themes identified in the literature rely heavily upon Isfandyari-Moghaddam and Kashi-Nahanji's 2010 study. Given the limitations of that research, these themes should be considered only as examples of prevalent themes, rather than as definitive themes in contemporary library cartoons.

Theme 1: Librarians are superhero material! In addition to the overt superhero depictions of librarians documented by Robert Hulshof-Schmidt (2008), researchers Isfandyari-Moghaddam \& Kashi-Nahanji (2010) found recurring images of librarians as helpful and powerful agents of information. 
Their research points to cartoons depicting library patrons being surprised by librarians' expertise and their ability to find the information users seek. Other examples depict librarians scaling the stacks like Spiderman or using rockclimbing gear to reach the top shelves, all in the name of book retrieval. The literature does not identify or discuss the closely related image of "the freedomfighter librarian," a recurring motif in recent editorial cartoons with Librarian-asSuperhero implications. Database searches, for instance, produced a number of images reflecting the idea that librarians work passionately to protect citizens' right to free speech, information access, and privacy, as seen in this 2006 editorial cartoon satirizing the Patriot Act:

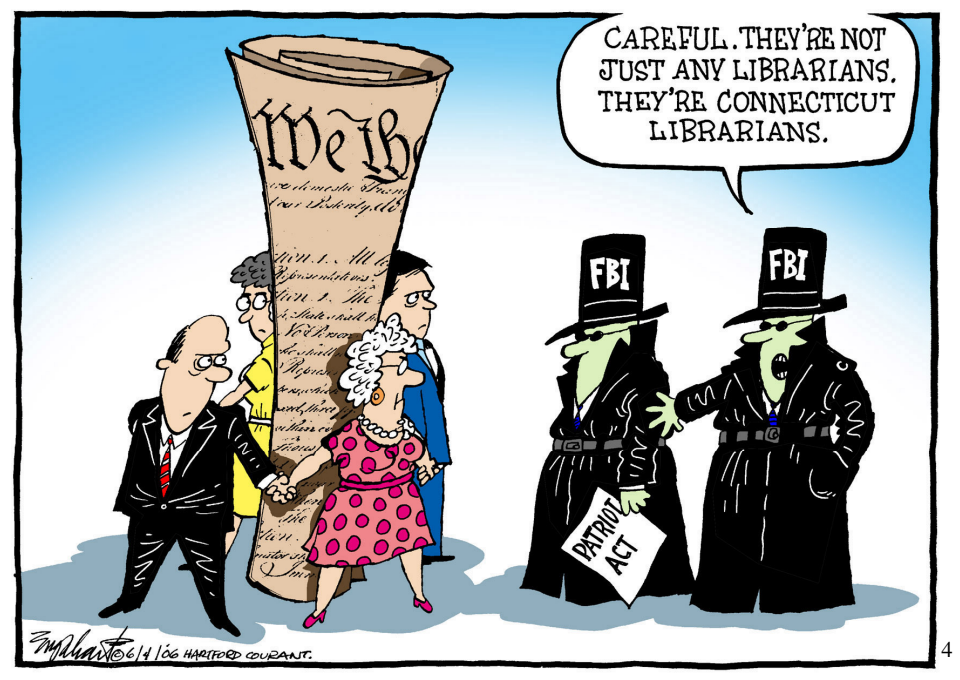

Theme 2: Librarians are sticklers for rules. A second common theme specific to the sub-category of librarians contradicts the super-librarian motif and depicts librarians as bored, irritated, dull bureaucrats. Isfandyari-Moghaddam and Kashi-Nahanji (2010) note: "Caricatures of librarians show their irritation and lack of interest in helping patrons, the dull seriousness and boredom of library atmosphere" (p. 3). Isfandyari-Moghaddam and Kashi-Nahanji identify two specific images that recur in their sample of library cartoons: The stereotypical librarian's insistence on silence and the oft-ridiculed librarian fixation on retrieving overdue fines.

Theme 3: Libraries are obsolete. A third identified theme depicts libraries as useless, poorly-run public institutions. In an editorial, Library Journal Editorin-Chief Francine Fialkoff (2007) discusses the prevalence of this theme evident in a recent New Yorker cartoon, "The Reading Room," which depicts a futuristic

${ }^{4}$ Englehart, B., 2006. Reprinted with permission. 
library. To highlight the underlying message that libraries are becoming obsolete, Fialkoff points to such details as the absence of librarians, books, and community: "almost everyone has a headset on" (p. 8). Additionally, computers and popculture references have replaced traditional library icons in the cartoon. In fact, the only books present in the image, Fialkoff notes, are in a box labeled "Bums Only" (p. 8).

Isfandyari-Moghaddam and Kashi-Nahanji (2010) similarly point to images depicting low numbers of library clients as the most prominent evidence of library obsolescence. Their research further identifies comic depictions of library inefficiencies, including: "the existence of multiple rules to perform a single task, the classification and organization of reference materials...and lack of standardized principles" (p. 4).

Sub-themes to the demise of libraries that are not noted in the literature but are evident in database searches of library cartoons include images depicting the effects of budget cuts: boarded-up libraries, reduced hours, and institutional desperation, with some cartoons depicting extreme attempts at attracting patrons, such as advertizing free porn on library computers (Ackerman, 2004).

Theme 4: The Internet is the new library. An emerging theme in library cartoons touches upon digitization and implies that people prefer to access information electronically (Isfandyari-Moghaddam \& Kashi-Nahanji, 2010). Recent library cartoons abound with images of eBooks and iPads filling the stacks. One cartoon shows old books supporting a desk topped with a computer; the caption reads, "We've found a use for all the old books."

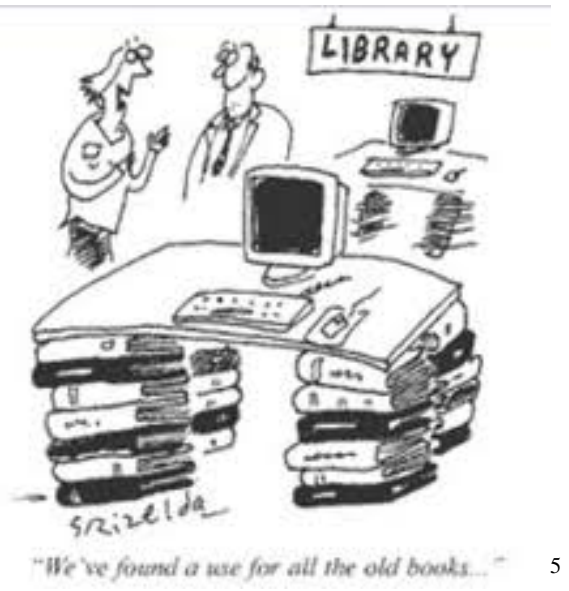

Another recent cartoon depicts a grandmother explaining to her wide-eyed grandson that a library is an ancient ancestor of the Internet:

\footnotetext{
${ }^{5}$ Grizelda. Copyright by Grizelda. Reprinted with permission.
} 


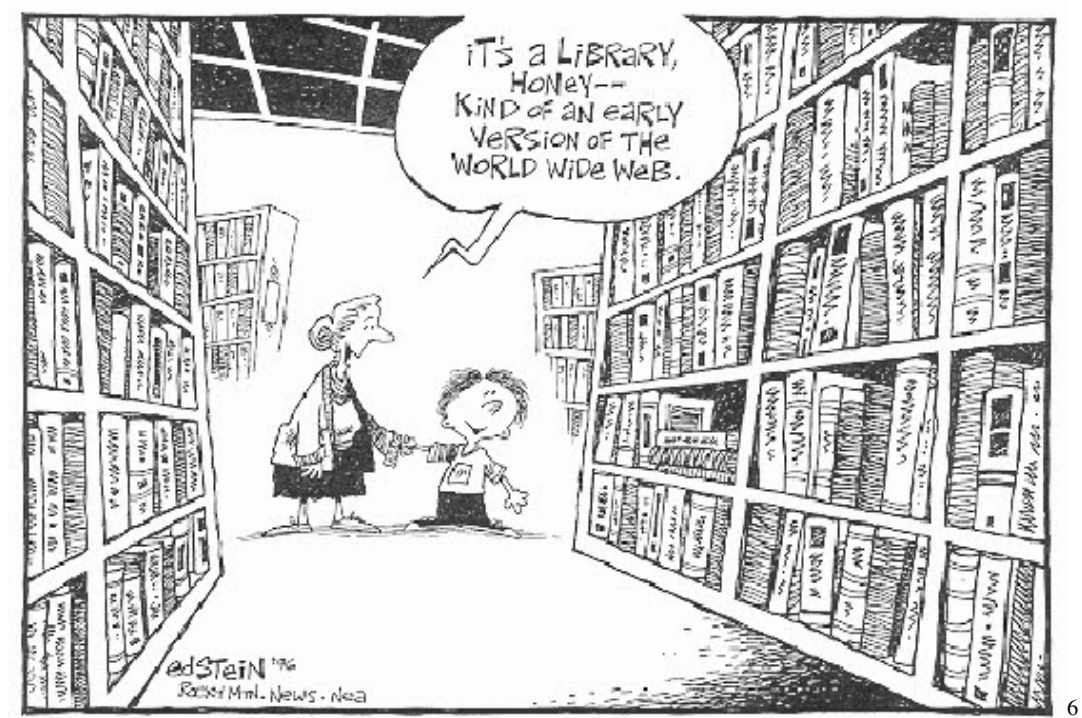

The digitization theme has even infiltrated comic books, notes HulshofSchmidt (2008): "Over the past decade, costumed heroes have increasingly used online resources ... nearly as much as muscles and utility belts to defeat injustice and tyranny" (p. 27).

\section{The VAlue OF Library Cartoons}

A final topic in the literature on library cartoons discusses the value of studying library-themed comic art. Here, two arguments emerge: The first asserts that library cartoons can enhance information workers' understanding of the public's perception of libraries, particularly in recognizing misperceptions or areas of weakness. In their article "Repartee," Holley and Stevens (1969) suggest that an extensive collection of library cartoons "might be very instructive in studying the popular image of the librarian and the library and how it has changed over time" (p. 175).

Francine Fialkoff (2007) presents a similar view in her analysis of Bruce McCall's New Yorker cartoon depicting a futuristic library empty of books and librarians. She warns: "The illustration points to some very real perception problems that no amount of marketing and outreach has yet corrected: the idea that libraries are perfectly fine without librarians, or that books will surely disappear from them. ... We need to do a lot more to answer the, "Why do we need a library anyway?' question if this vision permeates our culture” (p. 8).

\footnotetext{
${ }^{6}$ Stein, E., 1996. Copyright 1996 by Ed Stein. Reprinted with permission.
} 
Isfandyari-Moghaddam and Kashi-Nahanji (2010) illustrate this perspective in their effort to identify negative and weak statements about libraries through cartoon analysis. They conclude that information workers may benefit from paying attention to negative depictions of libraries in caricatures. They argue that thinking critically about library cartoons, while actively working to improve the perceived weaknesses of libraries and librarians, will educate information workers about ways to dispel the negative public perception of libraries reflected in these caricatures.

The assumption that library-themed cartoons accurately reflect public opinion about libraries, however, requires examination. While some library professionals such as Holley and Stevens (1969) rely upon this assumption, others have reported that the art of caricature has a lag time and does not necessarily reflect current opinion. Ohio State University Assistant Professor of Sociology Katherine Meyer and colleagues (1980), for instance, note that comic art of the free speech movement of the early 1960s did not appear in print until 1971. A study analyzing cartoons from the 1995 World Conference on Women similarly found that the caricatures primarily depicted media-driven stereotypes of women with little or no connection to the issues highlighted at the conference (Gilmartin \& Brunn, 1998). Hence it is incorrect to assume, as have several abovementioned scholars, that library-themed cartoons accurately reflect a negative public perception of libraries.

The second area of discussion on the value of studying library cartoons argues that library cartoons can be used as a tool to influence public opinion of libraries. Hulshof-Schmidt (2008) writes that many libraries have successfully used the superhero-librarian image for promotional purposes. The Super Librarian Campaign, launched by the New Jersey State Library in 2003, for instance, introduced a new superhero-librarian who is "faster than searching the World Wide Web," and "able to answer any question with insight and detail" (NJ State Library, 2003). The response to this campaign was overwhelming: The Super Librarian website received enthusiastic patron support and 50,000 hits in the first eight months (Keresztury, 2004).

Related studies on the power of caricature suggest that library cartoons can serve as a wakeup call to knowledge workers and even act as agents of change. Writing about a recent controversy in Denmark over caricatures of the Islamic Prophet Muhammad, Hans Rask Jensen (2008) notes that these inflammatory caricatures prompted the small Muslim community in Denmark to organize and successfully implement an international boycott of Danish products in Middle Eastern countries. In his study that examined cartoons about the influx of migrant workers in Canada, Josh Greenberg (2002), of McMaster University, writes that "cartoons seize upon and reinforce common sense and thus enable the public to 
classify, organize, and interpret in meaningful ways what they see or experience about the world at a given moment" (p. 181).

Finally, in their paper "Exploring the Effects of Editorial Cartoons on Attitude Change," researchers Neuberger and Kremar (2008) report experiment-based findings that editorial cartoons may have a significant attitudinal effect on issues requiring a low level of viewer engagement. The same experiments determined that editorial cartoons may even have persuasive power when combined with written articles on the same topic. This power to influence is precisely why some editorial cartoonists, who have touched upon controversies too inflammatory for the audience they serve, have been fired from their jobs (Danjoux, 2007) and why unfavorable depictions of the Prophet Muhammad could lead to protests around the world (Kuipers, 2011).

\section{CONCLUSION}

Several conclusions may be drawn from the collective literature on library cartoons. The research shows, for instance, that comic art featuring libraries has a noteworthy history with a variety of themes. Analyzing recent themes may provide information workers with new insight to public perception of libraries, inspire improvements in library practices, and even influence public attitude toward libraries. Still, significant literature gaps surround the topic and highlight areas ripe for future research.

Foremost in need is a comprehensive content analysis of U.S. library-themed cartoons dating from the late 1800s to present day. Such research would begin to identify enduring themes, enhance understanding of the significance of libraries during challenging moments in American history, and potentially aid the assessment of people's attitudes toward libraries. Additionally, such study would begin to identify unreported trends in the field of library science over time and address many questions that have never been examined, for instance: What are the earliest library cartoons in this country? Reviewing library-themed cartoons that appeared in newspapers during poignant moments in American history - the Great Depression or the McCarthy era, for instance-could further provide extraordinary insight into the role of libraries during times of nationwide financial or social crisis.

With a comprehensive study of library cartoons, researchers could begin to analyze how themes have changed over time-especially since the Internet became a widespread research tool. Such investigations might offer insight to another research question: How have technological advancements in information science impacted libraries and altered the public's perception of them? A comprehensive review of thematic changes in relation to technological advancements and other external events recorded in library cartoons may offer 
key insight to information professionals. Research findings on this matter could arguably reveal previously unidentified perceptions of libraries, which, according to some scholars, could ultimately inspire improvements in services.

Additionally, a complementary study of the use of library cartoons as agents of change could provide library professionals with valuable examples of how to reach a wide audience. Unlike written editorials or laborious essays deconstructing current issues, cartoons offer an easy point of entry for everyone-scholars, middle class families, teenagers, and non-English speakers - thereby informing viewers of issues they might otherwise ignore. Gilmartin and Brunn (1998), in their analysis of political cartoons featuring the 1995 World Conference on Women, write:

And because political cartoons can be understood at a glance, they reach more people than written editorial commentary; they can be taken in by 'skimmers,' those people who glance across an editorial page but do not take the time to read its text. (p. 536)

For example, a citizen who has not visited a library in years and, consequently, is disinclined to vote for a bond to finance library improvements, might be swayed to support the measure (or at least to think about the issue) upon seeing an editorial cartoon in which a child is walking away from a locked-up library saying, "Guess I'll go play some video games."

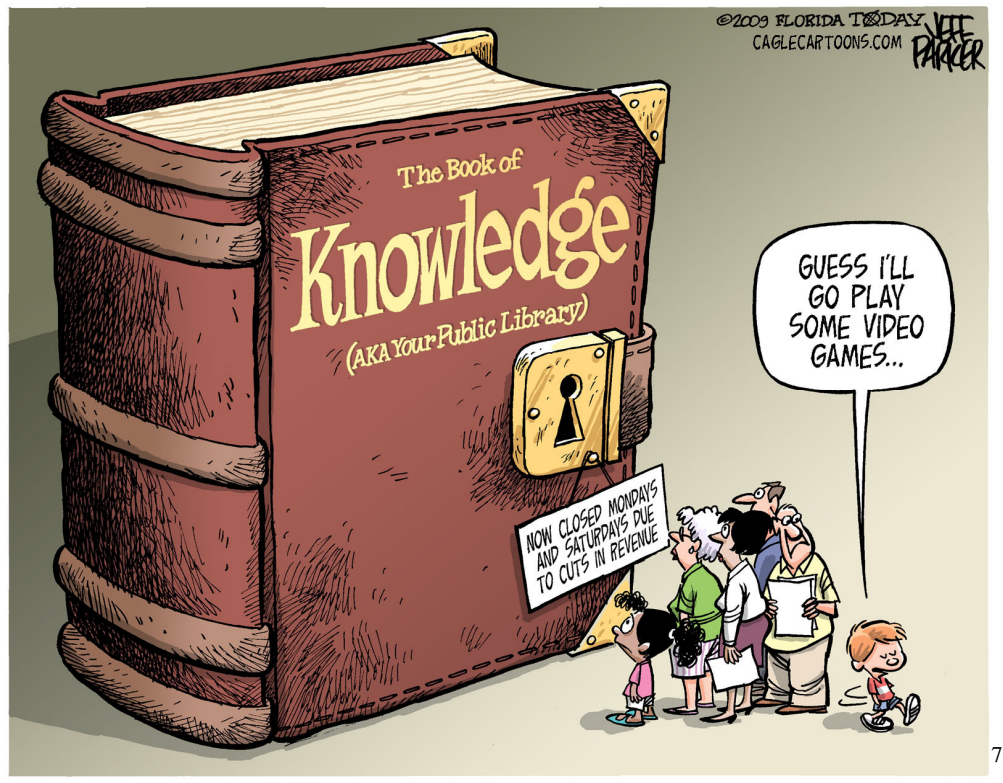

\footnotetext{
${ }^{7}$ Parker, J., 2009. Reprinted with permission.
} 
In addition to library cartoons' historical value and their potential use in understanding or reaching library patrons, it should be noted in this literature review that library cartoons are quite funny, prompting out-loud laughter, too. In existence in the U.S. since the 1800s, library-themed cartoons embody more than a century's worth of library-related humor. That trove constitutes a valuable artifact for library science as it would for any field or profession.

While laughter is, arguably, a priceless value, in the case of library cartoons, humor can provide retrospective relief to the present challenges of information professionals. For instance, knowing that cartoonists were mocking the shortage of library hours at the Astor Library in New York City in 1892 provides some comic relief to the current trend of reducing hours in public libraries. Perhaps cutting hours is not as cataclysmic to the future of libraries as it currently seems. Perhaps it is but one of many trends through which the institution cycles over time. Instead of worrying about the dire implications, perhaps a chuckle (and redirection of efforts) might well serve library and information professionals. In times of industry flux, laughing at the setbacks and idiosyncrasies of any public institution can go a long way.

\section{REFERENCES}

Ackerman. (2004, December 9). Why bother going to the adult bookstore. . . . The Oregonian. Retrieved from http://4.bp.blogspot.com/_RzmIlSwLsTQ/TOCdQIWMWXI/AAAAAAAA AZo/zyqyxbKtUEM/s1600/libraries_are_adult_bookstores_sm.jpg

Becker, S. (1959). Comic art in America: A social history of the funnies, the political cartoons, magazine humor, sporting cartoons, and animated cartoons. New York: Simon and Schuster.

Bergson, S. (2002). Librarians in comics: Sources: Comic strips. Retrieved from http://www.ibiblio.org/librariesfaq/comstrp/comstrp.htm

Brooks, C. (Ed.). (1990-2010). Best editorial cartoons of the year. Gretna, Louisiana: Pelican Publishing.

Cary, E. L. (1933). American caricature - past and present. Parnassus, 5(7), pp. 1-3. Retrieved from http://www.jstor.org.libaccess.sjlibrary.org/stable/770936

Danjoux, I. (2007). Reconsidering the decline of the editorial cartoon. PSOnline, (April), 245-247. doi:10.1017/S1049096507070370 
Dewey, D. (2007). The art of ill will: The story of American political cartoons. New York, NY: New York University Press.

Edwards, J. L., \& Ware, L. (2005). Representing the public in campaign media: A political cartoon perspective. The American Behavioral Scientist, 49(3), 466478. doi: 10.1177/0002764205279416

Fialkoff, F. (2007). The New Yorker on libraries. Library Journal, (May 1), 8. Retrieved from http://lj.libraryjournal.com/

Gilmartin, P., \& Brunn, S. (1998). The representation of women in political cartoons of the 1995 World Conference on Women. Women's Studies International Forum, 21(5), 535-549. doi:10.1016/S0277-5395(98)00063-6

Greenberg, J. (2002). Framing and temporality in politics cartoons: A critical analysis of visual news discourse. Canadian Review of Sociology, 39(2), 181198. doi: 10.1111/j.1755-618X.2002.tb00616.x

Hess, S., \& Northrop, S. (1996). Drawn \& quartered: The history of American political cartoons. Montgomery, Alabama: Elliott \& Clark Publishing.

Holley, E. G., \& Stevens, N. D. (1969). Repartee. The Journal of Library History, 4(2), 173-175. Retrieved from http://www.jstor.org/discover/10.2307/25540163?uid=3739560\&uid=2134\& uid=2\&uid=70\&uid=4\&uid=3739256\&sid=21101693779077

Hulshof-Schmidt, R. (2008). Look! up in the sky! it's a ... librarian? OLA Quarterly, 14(1), 7-27. Retrieved from http://www.olaweb.org/assets/documents/olaq_14no1.pdf

Isfandyari-Moghaddam, A., \& Kashi-Nahanji, V. (2010). An artistic horizon: Content analysis of caricatures with library and information science themes. Library Philosophy and Practice, 2010 (September). Retrieved from http://www.webpages.uidaho.edu/ mbolin/moghaddam-nahanji.htm

Jensen, H.R. (2008). The Mohammed cartoons controversy and the boycott of Danish products in the Middle East. European Business Review. 20(3), 275289. doi: 10.1108/09555340810871455

Keresztury, T. (2004). Super librarian to the rescue. Library Journal 129(9), 32. Retrieved from http://www.libraryjournal.com/article/CA415374.html 
Kuipers, G. (2011). The politics of humor in the public sphere: Cartoons, power, and modernity in the first transnational humor scandal. European Journal of Critical Studies, 14(1), 63-80. doi:10.1177/1367549410370072

Marín-Arrese, J. I. (2008). Cognition and culture in political cartoons. Intercultural Pragmatics, 5(1), 1-18. doi:10.1515/IP.2008.001

Meyer, K., Seidler, J., Curry, T., \& Aveni, A. (1980). Women in July fourth cartoons: A 100-year look. Journal of Communication, 30(1), pp. 21-30. doi:10.1111/j.1460-2466.1980.tb01764.x

Neuberger, L., \& Kremar, M. (2008, May 22). Exploring the effects of editorial cartoons on attitude change: An experimental analysis. Paper presented at the annual meeting of the International Communication Association. Montreal, Quebec, Canada. Retrieved from http://citation.allacademic.com/meta/p_mla_apa_research_citation/2/3/3/7/7/ pages233778/p233778-1.php

NJ state library: Super librarian. (2003). Retrieved from http://www.njlibraries.org/

Plourde, D. (2011). Library cartoons: An annotated bibliography. Retrieved from http://www.libraryhumor.com/index.html

Robb, J. E. (2009). Bill Blackbeard: The collector who rescued the comics. Journal of American Culture, 32(3), 244-256. doi:10.1111/j.1542734X.2009.00714.X

Rubin, R. E. (2010). Foundations of library and information science (3rd ed.). New York, NY: Neal-Schuman Publishers, Inc.

Taylor, R. (1938, October 15). A revised statuary ... The New Yorker. Retrieved from https://cartoonbank.licensestream.com/LicenseStream/Store/Content?Filter.S earchString=revised $\% 20$ statuary $\% 20$ for

Thomas, S. J. (August 2004). Teaching America's GAPE (or any other period) with political cartoons: A systematic approach to primary source analysis. The History Teacher, 37(4), 425-446. Retrieved from http://www.jstor.org/discover/10.2307/1555548?uid=3739560\&uid=2134\&ui $\mathrm{d}=2 \&$ uid $=70 \&$ uid $=4 \&$ uid $=3739256 \&$ sid $=21101693779077$ 
Wagner, C. (2005). Liberry funnies. Indiana Libraries, 24(2), 28-29. Retrieved from http://journals.iupui.edu/index.php/IndianaLibraries

\section{AdDENDUM: ONLINE Bibliographic SourCeS FOR CARTOON RETRIEVAL}

Ambaum, G., \& Barnes, B. (2008). Unshelved website. Retrieved from http://www.unshelved.com/

Association of American Editorial Cartoonists website. Retrieved from http://editorialcartoonists.com/

Cartoon America: Library of Congress Exhibition website. Retrieved from http://www.loc.gov/exhibits/cartoonamerica/cartoon-learnmore.html

Daryl Cagle's Political Cartoons website. Retrieved from http://www.politicalcartoons.com/.

Funny Times website. Retrieved from http://www.funnytimes.com.

Google Image. Retrieved from http://www.google.com/imghp?hl=en\&tab=wi

New York Times News Service/Syndicate website. Retrieved from https://www.nytsyn.com/cartoons

The Cartoon Bank website. Retrieved from http://www.condenaststore.com/st/Cartoons-By-Subject-Prints_c146314_htm

The Comic Strips. The Cartoonist Group. Retrieved from http://www.thecomicstrips.com/index_strip.php 